\title{
Polychaetes from the Caribbean coast of Colombia: An updated checklist and some taxonomic annotations
}

\section{Poliquetos de la costa Caribe en Colombia: una lista de chequeo actualizada y algunas anotaciones taxonómicas}

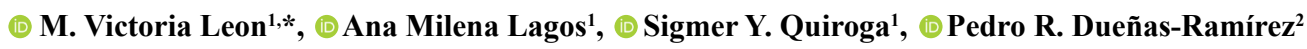 \\ ${ }^{1}$ Grupo de Investigación MIKU, Facultad de Ciencias Básicas, Universidad del Magdalena, Santa Marta, D.T.C.H., Colombia \\ ${ }^{2}$ Programa de Biología Marina, Universidad de Bogotá Jorge Tadeo Lozano, Santa Marta, Colombia
}

\begin{abstract}
We present an updated list of the polychaete species described for the Caribbean coasts of Colombia after a historical review of the literature. The taxonomic list includes references to the nomenclature, the synonymies, the data from the ecoregion, the habitat and the bathymetry. Based on the review, we were able to determine that up to September 2019, 51 families, 230 genera, and 293 species with scientific validity had been described for the Colombian Caribbean coast. Eunicidae is the family with the highest number of records, with a total of 33 (11.3\%) species, followed by Syllidae with 23 species (7.8\%) and Nereididae with 19 species (6.5\%). The Tayrona ecoregion presented the greatest diversity, with $32 \%$ of species records, followed by the Magdalena ecoregion with $23.4 \%$. Polychaetes in Colombia have been collected in natural habitats such as mangroves, seagrasses, and even as parasites and commensals of other organisms; however, about $60 \%$ of the taxonomic records correspond to organisms collected in soft and hard bottoms, mainly between 0 and $15 \mathrm{~m}$ deep. The descriptions and records of species on the Colombian Caribbean coast are due to the important contributions made in the 19th century by international and national researchers.
\end{abstract}

Keywords: Records; diversity; checklist; Polychaeta.

\begin{abstract}
Resumen
Se presenta una lista actualizada de las especies de poliquetos descritos para las costas del Caribe en Colombia con base en la revisión histórica de documentos. La lista taxonómica incluye referencias de nomenclatura, sinonimias, datos de la ecorregión, hábitat y batimetría. Mediante la revisión se pudo determinar que hasta septiembre del 2019 se han descrito 51 familias, 230 géneros y 293 especies con validez científica en la costa del Caribe en Colombia. Eunicidae es la familia con el mayor número de registros de especies, con un total de 33 (11,3\%), seguida de Syllidae, con 23 especies (7,8 \%), y Nereididae, con 19 especies (6,5\%). La ecorregión Tayrona fue la que presentó la mayor diversidad, con el $32 \%$ de los registros de especies, seguida de la ecorregión Magdalena, con 23,4 \%. Los poliquetos en Colombia se han recolectado en hábitats naturales como manglares, pastos marinos e, incluso, como parásitos y comensales de otros organismos; sin embargo, cerca del $60 \%$ de los registros taxonómicos corresponden a organismos recolectados en fondos blandos y duros, principalmente entre los 0 y $15 \mathrm{~m}$ de profundidad. Las descripciones y registros de especies en la costa Caribe colombiana se deben a las importantes contribuciones realizadas en el siglo XIX por investigadores internacionales y nacionales.
\end{abstract}

Palabras clave: registros; diversidad; lista de chequeo; poliquetos.

\section{Introduction}

Polychaetes comprise a group of annelids (segmented worms) that possess lateral fleshy extensions or parapodia bearing several chitinous bristles or setae from which its name is derived. Although Polychaeta is paraphyletic (Struck, et al., 2011; Purschke, et al., 2014; Weigert, et al., 2014), the term "polychaetes" is still used as a reference for taxonomic purposes (Dean, 2012; Tovar-Hernández, et al., 2014). Polychaetes are abundant and diverse in marine benthic environments (Seaver, 2003) where they play a critical role as part of processes such as bioturbation, recycling of nutrients, and transference of energy to upper levels in

\footnotetext{
*Corresponding autor:

M. Victoria Leon; mvleon0221@gmail.com

Received: December 11, 2018

Accepted: July 4, 2019

Editor: Nestor Campos
} 
the trophic web (Hutchings, 1998). On the other hand, they are considered as good bioindicators, especially of the contamination produced by organic matter and heavy metals (Dean, 2008).

Despite their importance, the biodiversity of polychaetes has not been completely assessed. The low sampling effort in some regions and the misidentifications made by inexperienced taxonomists make it difficult to assess with certainty the number of species and their distribution (Salazar-Vallejo \& Londoño-Mesa, 2004; Dean, 2012). Furthermore, compiling information is a difficult task due mainly to the lack of updated checklists and the large quantity of information published in journals with a restricted or regional distribution. Colombia holds an important representation of the Polychaeta fauna recorded in the Caribbean (Miloslavich, et al., 2010), and in that context, we are presenting an updated checklist of polychaetes to contribute a more accurate estimate of the number of species known in the Caribbean coast of the country.

\section{Materials and methods}

An updated list of polychaete records for the Caribbean coast of Colombia is presented (Table 1S, https://www.raccefyn.co/ index.php/raccefyn/article/view/802/2624). The information was gathered from 59 formal publications (scientific journals or books) including the most recent list of species (Báez \& Ardila, 2003) and ecological papers. All the species names and taxonomic authorities were corroborated against the World Register of Marine Species (WoRMS) database. The checklist includes the current valid names, synonyms, bathymetric ranges, habitat, and distribution for each species. A bathymetric range of 0 to 2 meters was assigned to those species recorded from mangroves. For records based on misidentifications, a superscript number was added to the reference indicating the author(s) who corrected the identification following the numbering of table $2 \mathrm{~S}$, https://www. raccefyn.co/index.php/raccefyn/article/view/802/2625. We kept the records of genera and species complexes in the list as they were reported; their validity, taxonomic status, and the confirmation of their presence in the region could be the purpose of further studies. This checklist is based on records made before September 2019. Additionally, we are presenting tables and graphics with the cumulative number of recorded species for each ecoregion.

\section{Results}

Historical review of Polychaeta richness. The former species Mastigonereis heterodonta, currently valid as Nereis (Perinereis) heterodonta, was the first and only polychaete recorded for Colombia during the 19th century (Schmarda, 1861). In the 20th century, the results of enormous oceanographic surveys, particularly the Museen von Leiden und Amsterdam (Augener, 1922; 1933a, b, c; 1934) and the Allan Hancock (Hartman, 1944) expeditions, were important contributions to the knowledge of polychaete fauna in the Caribbean, including some records for the coast of Colombia. Also in the same century, many foreign researchers also made important contributions (Zibrowius, 1969; Southward, 1972; Fauchald, 1973; Kirsteuer, 1973; Dexter, 1974). In the late 70 s and the beginning of the 80s, Colombian researchers emerged with some checklists and ecological studies (Palacios, 1978; Victoria \& Pérez, 1979; Rodríguez-Gómez, 1979; Dueñas, 1981). Since then, there has been a significant increase in the knowledge of polychaete diversity (Figure 1), particularly due to the contribution of Dueñas (1999), who made almost 250 reports of polychaetes for the Caribbean coast of the country.

Laverde-Castillo \& Rodríguez-Gómez (1987) compiled a list of species for the Caribbean coast of Colombia and contributed with 11 new records. Almost two decades later, Báez \& Ardila (2003) made a new checklist with 35 additional records. To date, it has not been possible to establish an accurate number of species for the Caribbean coast of Colombia, which has sometimes been overestimated by the addition of species recorded from unconventional literature and the inclusion of morph-species and frequently underestimated by the omission of some records from ecological articles. A comprehensive historical review was published by Londoño-Mesa (2017).

In the last 15 years, the number of new polychaetes reports increased by almost $20 \%$ with a rate of about four new records per year. Herein we present an updated checklist of polychaetes for the Caribbean coast of Colombia until September 2019. A total of 51 families, 230 genera, and 293 species have been recorded (Table 1S, https://www.raccefyn. co/index.php/raccefyn/article/view/802/2624). This number does not include nine species previously recorded as cf. (Victoria \& Pérez, 1979; Báez \& Ardila, 2003; Lagos, et al., 2018) and one species, Neoamphitrite amphitrite, considered questionable due to the lack of records in WORMS or in any other database. The family Eunicidae was best represented with 33 species $(11.3 \%)$, followed by Syllidae with 23 species (7.8\%) and Nereididae with 19 species (6.5\%) (Figure 2). The family Longosomatidae was recorded in an ecology paper (Guzmán-Alvis \& Solano, 1997) without mentioning a specific genus. Twenty-one species found in Colombia have been new to science, however, one has been invalidated (Eupanthalis oculata Hartman 1944 now Zachsiella nigromaculata (Grube, 1878), as it was considered a subjective synonym.

Habitat and spatial and bathymetrical distribution. The Caribbean coast of Colombia is divided into nine strategic ecoregions according to environmental, social, cultural, and political dimensions; six are continental, two insular, and one oceanic (Díaz \& Gómez, 2000). The Tayrona ecoregion is one of the smallest in coastal extension, however, $32 \%$ of all polychaetes have been recorded there. The Magdalena ecoregion is second in richness with $23.4 \%$, and the insular ecoregion (San Andrés and Old Providence), as well as the Guajira Ecoregion, each with $11.2 \%$ of the records, 
are third (Figure 3). Polychaetes in Colombia have been found inhabiting in mangroves, seagrass, and even as parasites and commensal of sponges, ascidians, crinoids, bivalves, and other polychaetes; they have also been found in artificial substrates such as wrecks, woodpiles, concrete remains, and plastic objects. However, about $60 \%$ of the records correspond to species dwelling on soft and hard bottoms (Figure 4). Regarding the bathymetrical distribution, individuals have been recorded in depths up to $2,875 \mathrm{~m}$, but most of them in the range between 0 to $15 \mathrm{~m}$ (Figure 5).

\section{Discussion}

Báez \& Ardila (2003) recorded 43 families, 138 genera, and 238 species of polychaetes; our update has increased these figures to 51, 230, and 293, respectively. Even including the number of polychaete species recorded in the country's
Pacific coasts (Londoño-Mesa, 2011), the total number would be small compared to the 1,500 species recorded in México alone (Tovar-Hernández, et al., 2014), or the 1,341 species recorded in Brazil (Lana, et al., 2017). This clearly shows the need to increase the number of taxonomic studies in Colombian waters. The estimate of species richness would be more accurate if further taxonomic revisions were carried out. For example, the revision of terebelids polychaetes in Colombia (Londoño-Mesa, 2011) led to a reduction in the number of recorded genera, but the number of species records increased in about 50\% (Londoño-Mesa, 2017). Likewise, there are cases of species complexes waiting to be solved such as Neanthes acuminata and N. caudata (Reish, et al., 2014), Lumbriconereis latreilli and L. floridiana (Carrera-Parra 2001), Cirriformia filigera and Timarete filigera (Magalhãe, et al., 2014), which could lead to an increase in the number of species records for Colombia.

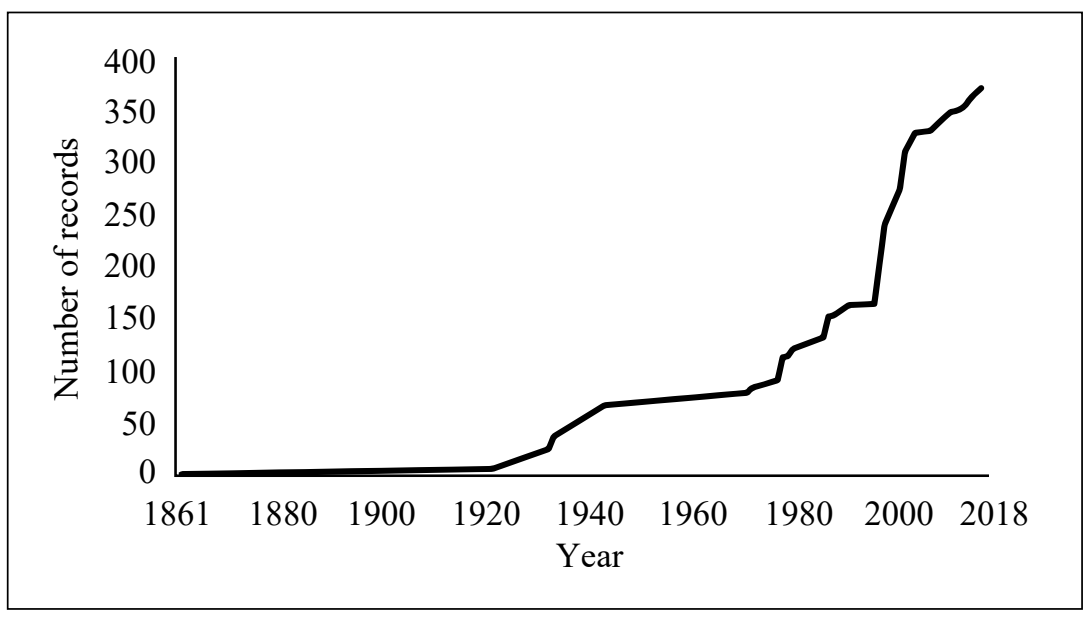

Figure 1. Cumulative curve of the number of new polychaete records along the Caribbean coast of Colombia

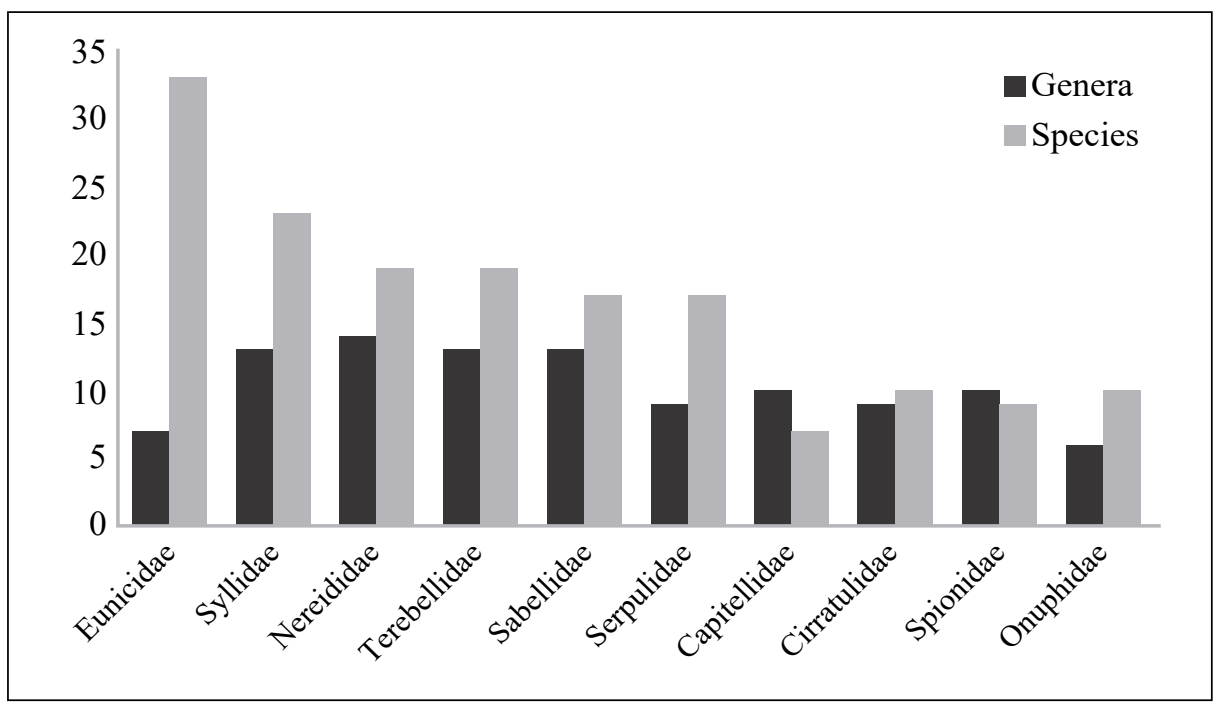

Figure 2. Main families according to the number of species and genera 


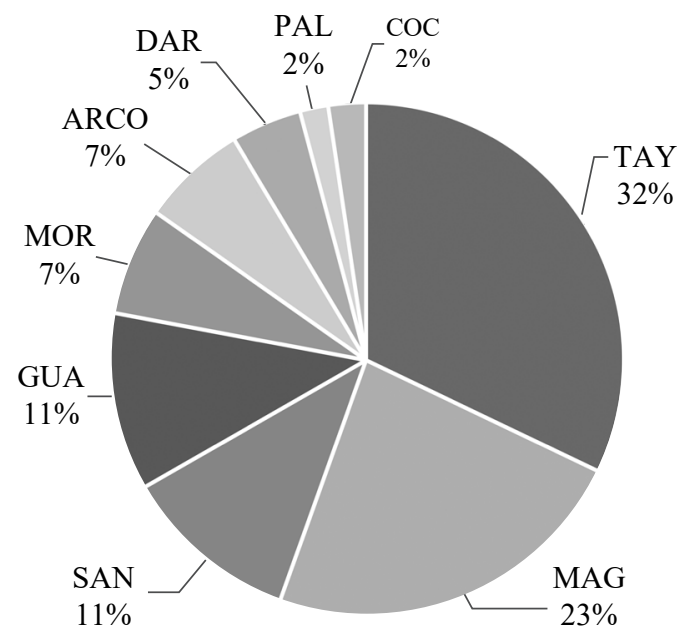

Figure 3. Relative dominance of species in each ecoregion. TAY: Tayrona ecoregion; MAG: Magdalena ecoregion; SAN: Archipelago of San Andrés and Providencia ecoregion; GUA: Guajira ecoregion; MOR: Golfo de Morrosquillo ecoregion; ARCO: Coral Archipelagos ecoregion; DAR: Darién ecoregion; PAL: Palomino ecoregion; COC: Oceanic Caribbean ecoregion
Species recorded for the first time in previous checklists lack species diagnoses, information on methods and habitat, and vouchers in biological collections. It is highly recommended that future surveys where new records are registered include such aspects and that specimens be deposited in biological collections so that they will be available when identifications need confirmation. Consequently, this will allow for more accurate estimates of diversity.

Bias in the records is evident. Families with high numbers of species records (e.g. Eunicidae, Syllidae, Nereididae, and Terebelidae) (Figure 2) are the consequence of the particular preference of some authors for those families. Families such as Spionidae and Capitellidae contribute considerably to the number of genera records because they are abundant in soft bottoms where most ecological studies or environmental assessments are performed, however, most of this type of studies rarely provide identification to the species level. Localities with high richness seem to be related to the closeness of the research institutes that have undertaken extensive scientific efforts to catalog their marine vicinities (Miloslavich, et al., 2010). The security and accessibility

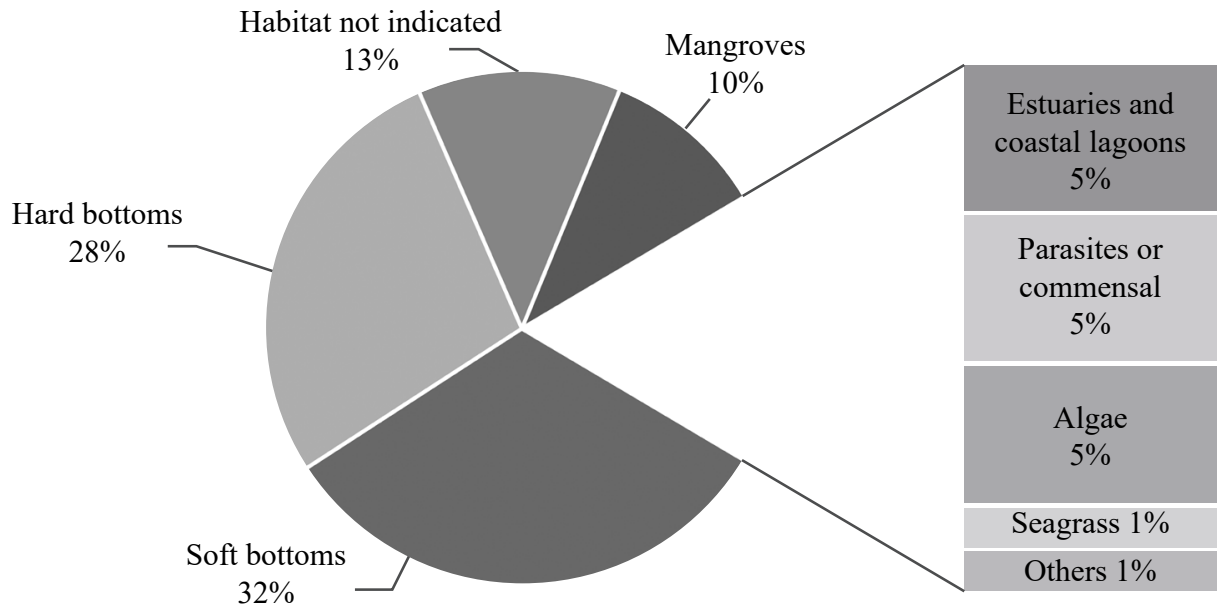

Figure 4. Main habitats of the species reported for the Caribbean coast of Colombia

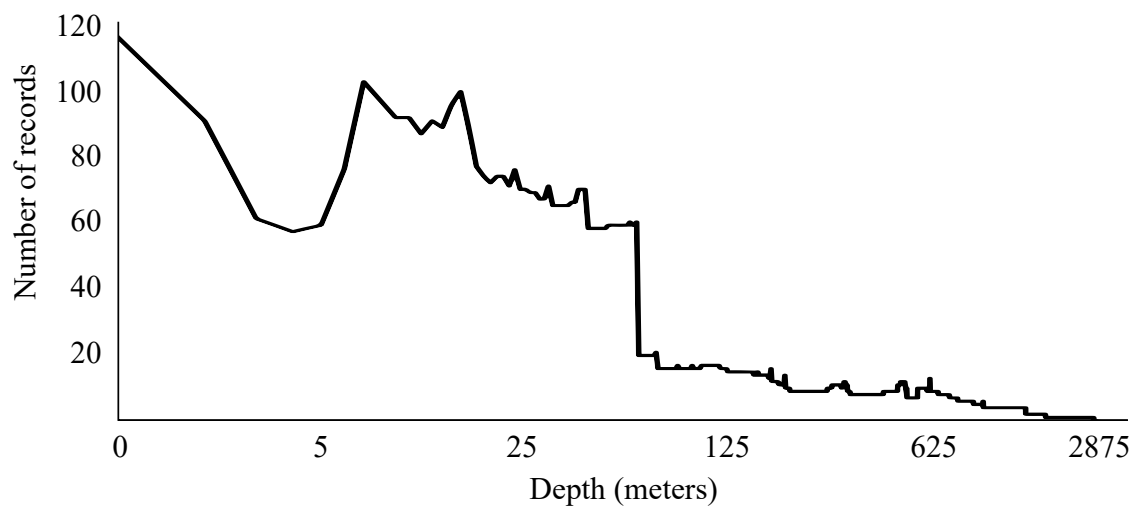

Figure 5. Bathymetric distribution of polychaete records along the Caribbean coast of Colombia 
to the different ecoregions also seem to have some impact on the knowledge of the polychaete diversity. Regarding the bathymetric distribution, most of the records came from depths up to $15 \mathrm{~m}$ where the sampling methods are easier and less expensive.

To have more comprehensive and accurate results of the diversity of polychaetes in the Caribbean coast of Colombia we recommend: 1) To focus on families with few species records; 2) to use integrative taxonomy methods to validate taxa; 3 ) to make a greater sampling effort in the ecoregions with few or no records; 4) to be more rigorous in the taxonomic work, which should include complete information on the habitat, bathymetric range, and ecological remarks, and to deposit the biological material examined in a scientific reference collection when new records are published.

\section{Acknowledgements}

This work had financial support from the Departamento de Ciencia, Tecnología e Innovación (Colciencias) (grant number 739-2017) and the Universidad del Magdalena.

\section{Authors' contributions}

M. Victoria Leon gathered the information, conducted the statistical analyses, and prepared the figures and tables. Ana M. Lagos, Pedro Dueñas, and Sigmer Quiroga helped compile and analyze data and contributed to the writing of the paper. Sigmer Quiroga translated the manuscript.

\section{Conflict of interests}

The authors declare that there is no conflict of interest of any kind that could possibly affect the publication or the results of this research process.

\section{Supplementary material}

Table 1S. List of polychaete records for the Caribbean coast of Colombia. See the table 1S in: https://www.raccefyn.co/index.php/ raccefyn/article/view/802/2624

Table 2S. List of publications that contributed to the gathered of information. See the table $2 \mathrm{~S}$ in: https://www.raccefyn.co/index. php/raccefyn/article/view/802/2625

\section{References}

Álvarez-León, R., \& Laverde-Castillo, J. A. (2003). Polychaetes from the Sur de Chengue (Magdalena) lagoon, Colombian Caribbean. Arquivos de Ciências do Mer. 36: 129-136.

Ardila, N.E., Fauchald, K., Lattig, P. (2005). Eunice colombia (Eunicidae: Polychaeta), a new species from the southern Caribbean. Proceedings of the Biological Society of Washington. 118: 259-263.

Arteaga-Flórez, C., Fernández-Rodríguez, V., Londoño-Mesa, M.H. (2014). First record of Ficopomatus uschakovi (Pillai, 1960) (Annelida, Polychaeta, Serpulidae) in the Colombian Caribbean, South America. Zookeys. 371: 1-11.
Arteaga-Flórez, C. \& Londoño-Mesa, M. H. (2015). Neréididos (Nereididae, Polychaeta, Annelida) asociados a raíces de mangle rojo, Rhizophora mangle, en Islas San Andrés y Providencia, Caribe colombiano. Boletín de Investigación Marina y Costera. 44 (1): 163-184.

Augener, H. (1922). Ueber litorale Polychaeten von Westindien. Sitzungsberichte der Gesellschaft. Naturforschender Freunde zu Berlin. 1922: 38-63.

Augener, H. (1933a). Polychaeten aus den zoologischen Museen von Leiden und Amsterdam. Zoologische Mededeelingen Leiden. 15: 177-260.

Augener, H. (1933b). Polychaeten aus den zoologischen Museen von Leiden und Amsterdam. Pt. II. Zoologische Mededeelingen Leiden. 16: 107-162.

Augener, H. (1933c). Polychaeten aus den zoologischen Museen von Leiden und Amsterdam. Pt. III. Zoologische Mededeelingen Leiden. 16: 177-260.

Augener, H. (1934). Polychaeten aus den zoologischen Museen von Leiden und Amsterdam. Pt. IV. Zoologische Mededeelingen Leiden. 17: 67-160.

Báez, D. P. \& Ardila, N. E. (2003). Poliquetos (Annelida: Polychaeta) del Mar Caribe colombiano. Biota Colombiana. 4 (1): 89-109.

Bastida-Zavala, J. R. \& ten Hove, H. (2002). Revision of Hydroides Gunnerus, 1768 (Polychaeta: Serpulidae) from the Western Atlantic Region. Beaufortia. 52 (9): 103-178.

Böggemann, M. (2005). Revision of the Goniadidae (Annelida, Polychaeta). Abhandlungen des Naturwissenschaftlichen Veriens in Hamburg. 39: 1-354.

Carrera-Parra, L. F. (2001). Lumbrineridae (Annelida: Polychaeta) from the Grand Caribbean region with the description of six new species. Journal of the Marine Biological Association of the United Kingdom. 81 (4): 599-621.

Dean, H. K. (2008). The use of polychaetes (Annelida) as indicator species of marine pollution: A review. Revista de Biología Tropical. 56 (4): 11-38.

Dean, H. K. (2012). A literature review of the Polychaeta of the Caribbean Sea. Zootaxa. 3596: 1-86.

Dexter, D. M. (1974). Sandy-beach fauna of the Pacific and Atlantic coasts of Costa Rica and Colombia. Revista de Biología Tropical. 22: 51-66.

de León-González, J.A. (1990). Dos serpúlidos nuevos para el Pacífico mexicano y duplicidad opercular en Hydroides crucigerus (Polychaeta: Serpulidae). Revista de Biología Tropical. 38 (2A): 33S-338.

Díaz, J. M. \& Gómez, D.I. (2000). Programa nacional de investigación en biodiversidad marina y costera (PNIBM). Santa Marta. INVEMAR, FONADE y MMA.

Dueñas, P. R. (1981). Inventario preliminar de los poliquetos (Annelida) de aguas someras de la Bahía de Cartagena y áreas adyacentes. Boletín del Museo del Mar. 10: 82-138.

Dueñas, P. R. (1999). Algunos poliquetos (Annelida) del Caribe colombiano. Milenio. 1: 9-18.

Dueñas-Ramírez, P. R. \& Dueñas-Lagos, A. (2016). Primer registro de Branchiomma coheni (Polychaeta: Sabellidae) en las costas del Caribe colombiano. Revista de ciencias marinas y Costeras. 8 (2): 101-105.

Dueñas-Ramírez, P. R. \& Quirós-Rodríguez, J. (2012). Presencia de Pseudonereis gallapagensis Kinberg, 1865 (Annelida: Polychaeta: Nereididae) en la costa Caribe colombiana. Revista Colombiana Ciencias Animales. 4 (2):454-457. 
Fauchald, K. (1969). A revision of six species of the flavusbidentatus group of Eunice (Eunicidae: Polychaeta). Smithsonian Contributions to Zoology. 6: 1-15.

Fauchald, K. (1973). Polychaetes from Central American sandy beaches. Bulletin of the Southern California Academy of Sciences. 72: 19-31.

Fauchald, K. (1992). A review of the genus Eunice (Eunicidae: Polychaeta) based upon type material. Smithsonian Contributions to Zoology. 523: 1-422.

Fernández-Rodríguez, V., Londoño-Mesa, M.H., RamírezRestrepo, J. J. (2016). Polychaetes from Red Mangrove (Rhizophora mangle) and their relationship with the water conditions in The Gulf of Urabá, Colombian Caribbean. Acta Biológica Colombiana. 21 (3): 611-618.

García, J.M. \& Palacio, J. (2008) Macroinvertebrados asociados a las raíces sumergidas del Mangle Rojo (Rhizophora mangle). Gestión y ambiente. 11 (3): 55-66

Guzmán-Alvis, A. I. \& Solano, O. D. (1997). Estructura de la taxocenosis Annelida-Mollusca en la región de Mingueo, Guajira (Caribe, colombiano). Boletín de Investigaciones Marinas y Costeras. 26: 35-52.

Guzmán-Alvis, A. I. \& Carrasco, F. (2005). Influence of a tropical lagoon discharge and depth on the structure of adjacent shelf macroinfauna (Southerm Caribbean). Cahiers de Biologie Marine. 46: 81-93.

Guzmán-Alvis, A., Solano O. D., Córdoba-Tejada, M., LópezRodríguez, A. (2001). Comunidad macroinfaunal de fondos blandos someros tropicales (Caribe colombiano). Boletín de Investigaciones Marinas y Costeras. 30: 39-66.

Guzmán-Alvis, A. I., Lattig, P., Ruiz, J. A. (2006). Spatial and temporal characterization of soft bottom polychaetes in a shallow tropical bay (Colombian Caribbean). Boletín de Investigaciones Marinas y Costeras. 35: 19-36.

Hartman, O. (1944). Polychaetous annelids. Reports of Allan Hancock Atlantic Expeditions. 3: 1-33.

Hutchings, P. (1998). Biodiversity and functioning of polychaetes in benthic sediments. Biodiversity Conservation. 7 (9): $1133-1145$

Kirsteuer, E. (1973). Uber das Vorkommen von Chaetopterus variopedatus (Annelida, Polychaeta) in einem karibischen Korallenriff. Zoologischer Anz. 1901-2: 115-123

Knight-Jones, P. \& Perkins, T.H. (1998). A revision of Sabella, Bispira and Stylomma (Polychaeta: Sabellidae). Zoological Journal of the Linnean Society. 123: 385-467.

Lagos, A. M., Leon, M. V., Quiroga, S., Martínez, A. (2018). Interstitial annelids from the Caribbean coast of Colombia. Revista de Biología Tropical. 66 (2): 658-673.

Lana, P.C, Pagliosa, P., Paiva, P.C., Carrerette, O., Paresque, K., de Matos Nogueira, J. M., Zacagnini Amaral, A. C., Steiner, T. M., Christoffersen, M. L., Senna Garraffoni, A. R., Di Domenico, M., Barroso, R., Rizzo A.E., Fukuda, M.V. (2017). Polychaetes in Brazil: People and places, past, present and future. En: Díaz-Díaz, O. D., Bone, C.; Rodríguez, T., Delgado-Blas V.H. (Editores). Poliquetos de Sudamérica, Volumen especial del Boletín del Instituto Oceanográfico de Venezuela. Cumaná: Fondo Nacional de Ciencia, Tecnología e Innovación (FONACIT). p. 24-50

Lattig, P. \& Martin, D. (2011). Sponge-associated Haplosyllis (Polychaeta: Syllidae: Syllinae) from the Caribbean Sea, with the description of four new species. Scientia Marina. 75 (4): 733-758.
Laverde-Castillo, J. A. (1992). Occurrence of Grubeulepis westoni Pettibone (Annelida: Polychaeta: Eulepethidae) in the Colombian Caribbean. Anales del Instituto de Investigaciones Marinas de Punta Betín. 21: 131-134.

Laverde-Castillo, J. \& Rodríguez-Gómez, H. (1987). Lista de los poliquetos registrados para el Caribe colombiano, incluyendo comentarios sobre su zoogeografía. Anales del Instituto de Investigaciones Marinas de Punta Betín. 17: 95-112.

Londoño-Mesa, M. H. (2011). Terebélidos (Terebellidae: Polychaeta: Annelida) del Caribe colombiano. Biota Colombiana. 12 (1): 17-34.

Londoño-Mesa, M. H. (2012). New species of Pista Malmgren, 1866 (Polychaeta: Terebellidae) from the Caribbean. Zootaxa. 3317: 39-48

Londoño-Mesa, M. H. (2017). Poliquetos de Colombia: un reto para la megadiversidad. En: Díaz-Díaz, O., Bone, D., Rodríguez, C.T., \& Delgado-Blas, V.H. (Editores). Poliquetos de Sudamérica, Volumen especial del Boletín del Instituto Oceanográfico de Venezuela. Cumaná: Fondo Nacional de Ciencia, Tecnología e Innovación (FONACIT). p. 71-88.

Londoño-Mesa, M. H. \& Arteaga-Flórez, C. (2016). Gusanos marinos de manglares del Golfo de Urabá. 177-219. En: Blanco-Libreros, J. F. \& M. H. Londoño-Mesa (Editores). Expedición Caribe sur: Antioquia y Chocó costeros. Bogotá (323): Secretaría Ejecutiva de la Comisión Colombiana del Océano.

Londoño-Mesa, M. H., Polanía, J., Vélez, I. (2002). Polychaetes of the mangrove-fouling community at the Colombian Archipelago of San Andrés and Old Providence, Western Caribbean. Wetlands Ecology and Management. 10: 227-232.

Maciolek, N. J. \& Holland, J. S. (1978). Scoloplos texana: A new orbiniid polychaete from South Texas, with notes on the related species Scoloplos treadwelli Eisig. Contribution to Marine Science. 21: 161-169

Magalhães, W. F., Seixas, V. C., Paiva, P. C., Elias, R. (2014). The Multitentaculate Cirratulidae of the genera Cirriformia and Timarete (Annelida: Polychaeta) from shallow Wwters of Brazil. PLoS ONE. 9 (11): e112727.

Miloslavich, P., Díaz, J. M., Klein, E., Alvarado, J. J., Díaz, C., Gobin J., Escobar-Briones, E., Cruz-Motta, J. J., Weil, E., Cortés, J., Bastidas, A. C., Robertson, R., Zapata, F., Martín, A., Castillo, J., Kazandjian, A., Ortiz, M. (2010). Marine Biodiversity in the Caribbean: Regional Estimates and Distribution Patterns. PLoS ONE. 5 (8): e11916.

Molina-Acevedo I. C. \& Londoño-Mesa, M. H. (2015). Terebélidos (Annelida: Polychaeta: Terebellidae) de Isla Fuerte, Caribe Colombiano. Boletín de Investigaciones Marinas y Costeras. 44 (2): 253-279

Palacios, J. (1978). Variación de la fauna de invertebrados del área estuárica de la Ciénaga Grande de Santa Marta en relación con los cambios de salinidad. Anales del Instituto de Investigaciones Marinas de Punta Betín. 10: 111-126.

Perkins, T. H. (1980). Review of species previously referred to Ceratonereis mirabilis, and descriptions of new species of Ceratonereis, Nephtys, and Goniada (Polychaeta). Proceedings of the Biological Society of Washington. 93 (1): $1-49$. 
Perkins, T. H. (1984). Revision of Demonax Kinberg, Hypsicomus Grube, and Notaulax Tauber, with a review of Megalomma Johansson from Florida (Polychaeta: Sabellidae). Proceedings of the Biological Society of Washington. 97: 285-368.

Purschke, G., Bleidorn, C., Struck, T. H. (2014). Systematics, evolution and phylogeny of Annelida - a morphological perspective. Memoirs of Museum Victoria. 71: 247-269.

Quinceno, P. A. \& Palacio, J. A. (2008). Aporte al conocimiento de los macroinvertebrados asociados a las raíces del Mangle (Rizophora mangle) en la ciénaga la Boquilla, municipio de San Onofre, Sucre. Gestión y ambiente. 11 (3): 67-78

Quirós-Rodríguez, J., Dueñas, P. R., Campos, N. H. (2013). Poliquetos (Annelida: Polychaeta) asociados a algas rojas intermareales de Córdoba, Caribe colombiano Polychaetes (Annelida: Polychaeta) associated with intertidal red algae of Córdoba, Colombian Caribbean. Revista de Biología Marina y Oceanografía. 48 (1): 87-98

Reish, D. J., Anderson, F. E., Horn, K. M., Hardege, J. (2014). Molecular phylogenetics of the Neanthes acuminata (Annelida: Nereididae) species complex. Memoirs of Museum Victoria. 71: 271-278.

Reyes, R. \& Campos, N. (1992a). Moluscos, anélidos y crustáceos asociados a las raíces de Rhizophora mangle Linnaeus, en la región de Santa Marta, Caribe colombiano. Caldasia. 17 (1): 133-148.

Reyes, R. \& Campos, N. (1992b). Macroinvertebrados colonizadores de raíces de Rhizophora mangle en la Bahía de Chengue, Caribe colombiano. Anales del Instituto de Investigaciones Marinas y Costeras Punta Betín. 21: 101-116.

Rodríguez-Gómez, H. (1979). Poliquetos de aguas someras colectados en las Islas del Rosario. Anales del Instituto de Investigaciones Marinas y Costeras Punta Betín. 11: 27-29.

Rodríguez-Gómez, H. (1988). Contribución al conocimiento de los anélidos (Annelida: Polychaeta) de aguas someras en la bahía de Nenguange Parque Nacional Natural Tayrona, Colombia. Trianea. 2: 403-443.

Romero-Murillo, P. E. \& Polanía, J. (2008) Sucesión temprana de la taxocenosis Mollusca-Annelida-Crustacea en raíces sumergidas de mangle rojo en San Andrés Isla, Caribe colombiano. Revista de Biología Marina y Oceanografía. 43 (1): 63-74.
Schmarda, L. K. (1861). Neue wirbellose Thiere beobachtet und gesammelt auf einer Reise um die Erde 1853 bis 1857.1 Turbellarien, Rotatorien und Anneliden. 2: 1-164.

Salazar-Vallejo, S.I. (2012). Revision of Trophoniella Hartman, 1959 (Polychaeta, Flabelligeridae). Zoosystema. 34: 453-519.

Salazar-Vallejo, S. I. \& Londoño-Mesa, M. H. (2004). Lista de especies y bibliografía de poliquetos (Polychaeta) del Pacífico Oriental Tropical. Anales del Instituto de Biología de la Universidad Nacional Autónoma de México, Zoología. 75 (1): 9-97.

Seaver, E. C. (2003). Segmentation: Mono- or polyphyletic? The International Journal of Developmental Biology. 47: 583-595.

Southward, E. C. (1972). On some Pogonophora from the Carribbean and the Gulf of Mexico. Bulletin of Marine Science. 22 (4): 739-776.

Struck, T.H. (2011). Direction of evolution within Annelida and the definition of Pleistoannelida. Journal of Zoological Systematics and Evolutionary Research. 49: 340-345.

Tovar-Hernández, M. A., Salazar-Silva, P., De León-González, J. A., Carrera-Parra, L. F., Salazar-Vallejo, S. I. (2014). Biodiversidad de Polychaeta (Annelida) en México. Revista Mexicana de Biodoversidad. 85: 190-196.

Ten Hove, H. A. (1989) Serpulinae (Polychaeta) from the Caribbean: IV- Pseudovermilia madracicola sp. n., a symbiont of corals. Uitgaven Natuurwetenschnappelijke Studiekring vor Suriname en de Nederlandes Antillen. 123: 135-144.

Victoria, C. H. \& Pérez, M. E. (1979). Los taxa AnnelidaMollusca-Crustacea en las raíces sumergidas del mangle rojo en dos áreas costeras del Caribe colombiano. Informe Museo del Mar. 21: 1-27.

Weigert, A., Helm, C., Meyer, M., Nickel, B., Arendt, D., Hausdorf, B., Santose, S. R. Halanych, K. M., Purschke, G., Bleidorn, C., Struck, T. H. (2014). Illuminating the base of the annelid tree using transcriptomics. Molecular Phylogenetics and Evolution. 31 (6): 1391-1401.

WoRMS Editorial Board. (2019). World Register of Marine Species. Accessed on: 2019-03-30. Available from: http:// www.marinespecies.org at VLIZ

Zibrowius, H.W. (1969). Hydroides gairacensis Augener, 1934, a little known serpulid polychaete from Central and South America. Bulletin of Marine Science. 19: 366-376. 